\section{American Literature in Hungary}

Lehel Vadon: Az amerikai irodalom és irodaiomtudomány bibliográfiája a magyar idöszaki kiadványokban 1990-ig [A Bibliography of American Literature and Literary Scholarship in Hungarian Periodicals to 1990] (Eger, 1997)

To call this bibliography monumental is a rather modest form of acknowledging its significance. The culmination of a decade and a half of painstaking research, it will be an indispensable tool for Hungarian students of American literature for many years to come, and will assure Professor Vadon a lasting place in the history of the profession in Hungary. But as the short dedicatory passage tells us, it was Professor László Országh who first planted the idea in his young student's mind, thus the book is also a tribute to the memory of that great scholar and teacher.

The vast amount of material that it contains is easily accessible: the pattern in which the various bibliographical items are arranged rests on a few wellconsidered principles of classification. The authors who in one way or another have been brought to the notice of the Hungarian reader - and one would be hard put to it to find a single one that has escaped the editor's attention - follow each other in alphabetical order.
There are two basic classes for the material: elsödleges források (primary sources) and másodlagos források (secondary sources), which then are subdivided, according to the nature of the writings listed, into versek / elbeszélések / drámák / regényrészletek (poems / stories / plays / excerpts from novels), etc. and tanulmányok / esszék / cikkek (studies / essays / articles), etc., respectively. This section takes up by far the greatest part of the book. But what follows it is, in its way, no less impressive: there is, in the final quarter of the book, a bibliography of unidentified authors, of folk poetry, as well as a general bibliography of a large range of fields from prose fiction to miscellaneous writings; thrown in for good measure, there is also a list of bibliographies concerned with aspects of the reception of American literature in Hungary.

The true test of a bibliography is in its use. The random checks I have made suggest that Professor Vadon's work will pass that test with flying colours. But usability, in the conventional sense, is not all there is to a book of this kind. If it is good, a bibliography can also be a most exciting read, and can set the mind in motion as effectively as any essay or study built on a sustained argument. Like so many other products of the intellect, bibliographies, by virtue of their contents, bear the imprint of history - in a way, they are history itself. 
What I mean is that the reception of American literature in this country, as reflected by the book under review, may also be read as a running commentary on (1) the history of Hungary, (2) the history of the United States, (3) the history of Hungarian-American relations and (4) the history of Hungarian literature - to name only a few of the subtexts within it. The changing fortunes of Howard Fast (before and after 1956), the relative popularity of Albert Maltz even in the fifties are inseparable from the political climate of the times; by the same token, the explosion in the translation of American literature from the sixties onwards has at least as much to do with the growth of the economic and political might of the United States as with the quality of the writing itself. The many translations of works by unidentified authors in much of the nineteenth century speak more eloquently of the state of Hungarian letters and of the international position of America than volumes of scholarship do. The list of the periodicals and newspapers that Professor Vadon has perused in the course of his research is not without lessons of this kind either. For most of us, Nagyvilág is the monthly periodical that for decades has performed a vital service for the reading public in this country by making the literature of other nations available in our language; I knew that there had been periodicals of that name earlier in the twentieth century, but I had no idea that the first Nagyvilág had seen the light of day as early as 1880 , to be followed by six more attempts to sell literature under this attractive heading. (Small comfort to the latest bearer of the name struggling heroically to get out of the desperate financial straits it has been in for quite some time now.) On top of all that, we are also given a bibliography not listed as such in the Contents, but tucked away in the Preface - of books by Hungarians dealing with this or that aspect of American literature.

As far as I can judge, all relevant publications - with the exception of daily papers where numbers had to be kept within manageable limits - have been examined. For all that, there are a few more, unexplored at present, which may be worth delving into. As reviews of the films of novels or plays do not lie beyond the horizons of this book, and as Film, Színház, Muziika is not ignored, the omission of Mozgó Képek (prominent in the 1980s) is an inexcusable oversight. (Let me treat myself to a little self-promotion: in view of the fact that it carried two short essays of mine, one on Doctorow and another on Henry James, in 1985 and 1988 , that now defunct monthiy might have raised the number of itens in this book from 9920 to at least 9922.) 
Making suggestions like this may, under the circumstances, amount to bad manners. From circumstantial evidence I gather that Professor Vadon has done most of the job single-handed, and no broadening of the scope seems practicable without the creation of a proper research team, which, in the final analysis, is a question of money. In persuading the people who hold the purse strings, this very book is a most powerful argument, and one can only hope that it will be used for the purpose. The material, to the best of my knowledge, is computerised, and a sequel is planned to bring (and, hopefully, also to keep) the bibliography up to date. This, among other things, means that it will be comparatively easy to make ciranges and corrections in any new edition. It is on these assumptions that $I$ raise the queries that follow.

(1) What exactly are the criteria by which the credentials of an author can be authenticated as American? Professor Vadon is more generous in this respect than the immigration laws of the United States were in the late nineteenth cen. tury; tighter controls, it seems, would have been beneficial. Joseph Brodsky's or Vladimir Nabokov's citizenship in American letters is indisputable, but try as I may, I fail to find any grounds on which André Breton or Hans Arp could be granted similar staius. Yet they also figure in this bibliography. (I note with a sigh of relief that W. H. Auden does not, despite the many arguments in favour of including him as well.) I appreciate the editor's principled stand observable in the classification of authors into poets, novelists, etc., but the occasional breach of consistency for the sake of the less well-informed reader would have done no harm. Calling Isadora Duncan only "írónö" (writer), on account of her famous autobiography, without noting that she was first and foremost a dancer, is misleading. By the same token, once we have resigned ourseives to Hans Arp's presence, we expect some indication of the fact that his significance as sculptor and painter exceeds his significance as poet.

(2) Translated works appear only under their Hungarian tities. Most users of the book, I believe, would welcome the original titles in parentheses, as it is not always easy to trace the translator's version back to the original. (Apropos of tities: is it not possible that $A$ fekete fátyol alait [Cnder the black veil], listed on page 865 as the tale of an unidentified author, is in fact Hawthorne's "The Minister's Black Veil"?)

(3) The book is printed in large, legible type, which: is a welcome departure from the time-hallowed bibliographical tradition of small print and nearillegibility. Leafing through this large volume several times has, however, left me with the impression that in its pres- 
ent form it is too big and heavy, therefore not sturdy enough, to stand up to the wear and tear of frequent use. Small print, whatever its disadvantages, would have reduced the bulk and thus would have made the book easier to handle.

But these are matters which do not seriously mar the standing of this fine piece of scholarship. The proof-reader, however, was caught napping far too many times, and Professor Vadon's labour of love is disfigured, as a result, by an unacceptably high number of misprints. Open the book anywhere, misprints will stare you in the face. Names, titles, other verbal items whether in English or in Hungarian go through strange and sometimes funny metamorphoses. Winnesburg, Obio (63), Angie March (94), Osol-Creek (102), Richard Grautigan (119), Saymour: bemutatás (668), Heidegger doktor kisérlelte (311), etc. are blemishes that should have been eradicated. Is the periodical that carried translations of the "American poet" André Breton Arkánum or Akánum (121)? Closer to home, I keep my fingers crossed that the now excellent chances that two of my eminent colleagues stand to attain immortality will not be irreparably damaged by their occasional assumption of the false names of Dávidházy and Mesterházy. (They may take some comfort from the fact that I have suffered the same fate at the hands of the whimsical printer.) We should not despair, however. Is thenc anyone in the profession who does not know whom the names "Szobodka" Tibor and "Heman" Melville conceal or who their "irdalmi merterei" were? And lest William Jay Smith should sink into complete oblivion owing to his new persona as William Jaysmith (both on page 370 where he is listed and in the Index [Névmutató]), let me mention that this Southern poet and tireless translator of Hungarian poetry was born in 1918, as one can learn from the biographical note in Gyula Kodolányi's anthology Szavak a szélbe (Budapest: Európa, 1980). And as he has only recently paid yet another visit to this country, we may assume that he is still hale and hearty, so the question marks filling the place where the dates of his birth and death should stand, may be ignored. I was, by the way, surprised that neither his Át a tii fokán (Budapest: Európa, 1976), nor the autobiographical Laktanya ivadék [Army Brat] (Budapest: Európa, 1981) received any critical attention.

This, however, is not the right note on which to end my review. The right note is the note of acknowledgement. And it is also the note of anticipation expressing the hope that the planned sequel to the book will also become available in the not too distant future.

ALADÁR SARBU 